DOI: $10.14746 /$ por.2018.2.5

\title{
MITOLOGIE POWIEŚCIOPISARSTWA HISTORYCZNEGO (NA WYBRANYCH PRZYKŁADACH Z LITERATURY POLSKIEJ PO 1945 ROKU)
}

\author{
Pawee TomczoK ${ }^{1}$ \\ (Uniwersytet Śląski w Katowicach)
}

Słowa kluczowe: powieść historyczna po 1945 roku, literatura popularna, nowoczesność

Keywords: historical novel after 1945, modernity

\begin{abstract}
Abstrakt: Paweł Tomczok, MITOLOGIE POWIEŚCIOPISARSTWA HISTORYCZNEGO (NA WYBRANYCH PRZYKŁADACH Z LITERATURY POLSKIEJ PO 1945 ROKU). „PORÓWNANIA” 2 (23), 2018. T. XXIII, S. 63-73. ISSN 1733-165X. Artykuł jest próbą ujęcia wizerunków, jakie zaprezentowali w wywiadach, posłowiach czy wstępach, a także w esejach powieściopisarze historyczni okresu powojennego. Jako materiał ilustracyjny w artykule przytoczone zostały wypowiedzi Teodora Parnickiego, Hanny Malewskiej, Antoniego Gołubiewa, Elżbiety Cherezińskiej oraz Marcina Wolskiego. Ich wypowiedzi zostały ujęte w ramy czterech płaszczyzn, które definiowały możliwe pozycje, jakie zająć mógł powieściopisarz historyczny, gdy opowiadał o swojej pracy pisarskiej. Te cztery płaszczyzny określają mitologię powieściopisarza historycznego, a także możliwości budowania swoistego antymitu opartego na negacji podstawowych wyznaczników literackiego mówienia o przeszłości.
\end{abstract}

Abstract: Paweł Tomczok, THE MYTHOLOGIES OF THE HISTORICAL NOVEL (BASED ON EXAMPLES FROM POLISH LITERATURE AFTER 1945). "PORÓWNANIA" 2 (23), 2018. Vol. XXIII, P. 63-73. ISSN 1733-165X. The article attempts to research the images of historical novelists in the post-war period of Polish literature. The basis of the research is a collection of interviews, prefaces, afterwords and criticisms by such authors as Teodor Parnicki, Hanna Malewska, Antoni Gołubiew, Elżbieta Cherezińska and Marcin Wolski. Their opinions are selected in four domains that defined the possible positions that could be taken by the historical novelists when they talked about their work. These four domains define the mythology of the historical novel as well as the possibilities of building a specific anti-myth based on the negation of the basic determinants of the way literature speaks about the past.

1 E-mail: pawel.tomczok@us.edu.pl, tomczok@wp.pl 


\section{Wstęp}

Powieściopisarstwo historyczne stanowi dość problematyczną część artystycznej nowoczesności - znajduje się bardzo często w opozycji wobec głównych nurtów estetycznych choćby dlatego, że nie spełnia warunków sztuki czystej i autonomicznej. Jako odrębny gatunek powieść historyczna powstaje w epoce romantyzmu, ale raczej jako jej boczna odnoga, trochę mniej skomplikowana, za to bardziej popularna wersja wielkich arcydzieł. Ale w XIX wieku to właśnie powieść historyczna wraz z innym formami powieści popularnej - zdobywa szeroką grupę odbiorców, stając się zarazem konkurentką nie tylko ambitniejszej literatury, ale też historiografii, która w właśnie w opozycji do literackich przedstawień przeszłości określa autonomię własnej dziedziny i metody badań.

W tej dość zawikłanej sytuacji kształtuje się nowoczesna mitologia powieściopisarza historycznego jako kogoś, kto potrafi ożywić dzieje, nadać im życiowe, bliskie czytelnikom kształty, a także połączyć obraz przeszłości z atrakcyjną fabułą (na temat poetyki klasycznej powieści historycznej zob. Bartoszyński 61-105). Taki splot materii historycznej i struktury fabularnej daje olbrzymie szanse afektywnego oddziaływania na czytelników, którzy w przedstawionych postaciach rozpoznać mogą nie tylko pojedynczych bohaterów, ale też reprezentacje narodu. Bohaterowie powieści Waltera Scotta czy Henryka Sienkiewicza odsyłają więc nie tyle do losów jednostki, co do sytuacji państwa zdolnego wyjść z opresji, podjąć walkę, by w końcu zwyciężyć. Powieściopisarz historyczny ma zatem narzędzia, by wykreować pojednanie między literacką jednostkowością a historyczną zbiorowością. W ten sposób ma szansę zdefiniować narodową fikcję, wokół której określić się może tożsamość zbiorowa.

Ten XIX-wieczny mit powieściopisarza historycznego opowiadającego społeczeństwu jego własne tradycje, dającego fikcje, z którymi można się utożsamić, dość często jest poddawany krytyce na przykład w XX-wiecznej refleksji nad sposobami ujmowania przeszłości. Wielokrotnie diagnozowany kryzys owej konwencji prowadzi jednak często do prób odnowy formalnej - popularne schematy fabularne próbuje się uzupełnić albo zastąpić formami literatury nowoczesnej, koncentrując się na przykład na psychologii historycznych postaci. Jednocześnie powieść historyczna bardzo mocno wikła się w różne dyskusje ideologiczne. Wielu twórców takich utworów deklaruje się jako marksiści czy katolicy, a ich powieści mają pokazywać z góry przyjętą obecność transcendentnego ładu w dziejach albo konflikt klasowy między wyzyskiwanymi a wyzyskującymi. Równie ważne zdaje się udzielenie odpowiedzi na różne aktualne spory polityczne - jak choćby pytanie o postać mocnego władcy, którego tak często pożądano i obawiano się w latach trzydziestych XX wieku, a jednocześnie wzorca którego poszukiwano w przeszłości. Z tych ideologicznych uwikłań wyłaniał się często model pisarstwa zaangażowanego, w którym powieściopisarz historyczny bezproblemowo przechodził do roli krytyka, eseisty 
czy działacza kulturalnego albo nawet politycznego. Mit powieściopisarza historycznego sytuował się zatem w opozycji do sztuki autonomicznej - bliższe mu było raczej proste zaangażowanie się po którejś ze stron, a jednocześnie ważna była troska o czytelnika, który powinien utwór zrozumieć bez większych problemów, a zarazem otrzymać jakąś formę satysfakcji odbioru.

Co dzieje się z omawianą mitologią po drugiej wojnie światowej? Oczywiście, w przypadku wielu tekstów bardzo istotne są ideologiczne uwikłania twórców. Trudno nie zauważyć, że w pierwszych latach po wojnie wiele powieści historycznych wydają autorzy określani jako katoliccy, z drugiej zaś strony ukazuje się bardzo wiele utworów pisanych z perspektywy lewicowej (zob. Szymutko 33-60). Ale w kolejnych latach pojawia się coraz więcej tekstów, które trudno zaliczyć do modelu literatury zaangażowanej. Podobnie w przypadku opozycji literatury popularnej i literatury wysokiej - mimo przewagi utworów nastawionych na zaspokojenie potrzeb i możliwości czytelnika pojawiają się utwory eksperymentalne, dążące do przekroczenia ograniczeń konwencji. Powieść historyczna, która jeszcze w dwudziestoleciu zdaje się realizować bardzo określone możliwości „języka modernizmu" (zob. Nycz 19), w czasach powojennych ulega zróżnicowaniu, jakby zajmując wszelkie pozycje systemu nowoczesnej literatury. To nowe usytuowanie oznacza, że wielu powieściopisarzy będzie musiało na nowo określić swoje zadania i zarazem stworzyć nowe mitologie, czasem zakotwiczone w kulturze modernistycznej, ale często bliższe już postmodernizmowi (na temat powieści historycznej zob. Burska; Chomiuk).

Celem artykułu jest omówienie mitologii artystycznych, które tworzą autorki i autorzy powieści historycznych od czasów powojennych do czasów najnowszych. Wykorzystane zostaną poglądy Hanny Malewskiej, Antoniego Gołubiewa, Teodora Parnickiego, Elżbiety Cherezińskiej oraz Marcina Wolskiego. Wizerunki pisarzy zostaną zrekonstruowane na podstawie różnych paraliterackich form wypowiedzi takich jak wstępy, posłowia, eseje i wykłady na temat gatunku powieści historycznej, a także licznych wywiadów. W tych pozapowieściowych tekstach twórcy konstruują obrazy własnej pracy - sposobu pisania, gromadzenia źródeł, lektur historycznych i literackich. $W$ analizowanych wypowiedziach powracają podobne tematy, często jednak ujmowane z różnych perspektyw. By je uporządkować, chciałbym zaproponować cztery płaszczyzny, w ramach których pisarze dokonują własnej identyfikacji. Każda z tych płaszczyzn wynika z synkretycznego charakteru powieści historycznej jako gatunku literackiego zawieszonego pomiędzy literaturą a historiografią, przeszłością a współczesnością i aktualnością polityczną oraz ideologiczną, popularną literaturą rozrywkową a ambitną literaturą wysoką oraz określonego przez stosunek do klasycznego modelu powieści historycznej reprezentowanej przez powieści Waltera Scotta, a w kontekście polskim przez Henryka Sienkiewicza.

Ze względu na ograniczenia miejsca zdecydowałem się poddać analizie kilku pisarzy, zrezygnowałem także $\mathrm{z}$ opisu funkcjonowania mitologii w krytycznym 
i czytelniczym odbiorze. Wspomnieć jednak należy, że w odniesieniu do takich pisarzy jak Parnicki czy Gołubiew ukształtowały się specyficzne mitologie krytyczne osadzone w trudności odbioru wielotomowych dzieł. Z tymi mitologiami odbioru autorzy często podejmują polemiczną grę, niejednokrotnie zaś wykorzystują je dla lepszego przybliżenia charakteru własnego pisarstwa.

\section{Twórca wobec historii. Epistemologia historii a mit źródła}

Pierwszy temat wyznacza bardzo ważna część definicji powieściopisarstwa historycznego, które powinno liczyć się z faktami historycznymi. Pojawia się tu problem wiarygodności wizji zaprezentowanej w dziele literackim, sprowadzonej najczęściej do zgodności przedstawienia z tekstami źródłowymi oraz aktualnymi badaniami historyków. Problematyka epistemologii historii, bardzo popularna w czasach powojennych, pozwalała wielu pisarzom nie tylko zachować wiarygodność, lecz także wskazać bariery dyskursu historycznego, który również podlega ograniczeniom poznawczym. Wielu pisarzy mogło zatem zaproponować wizerunek powieściopisarza historycznego, który nie tyle popularyzuje prace historyków, co pokazuje, że przeszłość sama w sobie jest niepoznawalna, my zaś dysponujemy jedynie różnymi - mniej lub bardziej prawdopodobnymi - wersjami zdarzeń. Ten motyw pojawia się w wypowiedziach wielu pisarzy, jak choćby u Teodora Parnickiego czy Hanny Malewskiej, dla których podkreślanie ograniczeń historii stało się ważnym narzędziem definiowania własnego stanowiska. Autorka Przemija postać świata wychodzi od spostrzeżenia, że historycy bardzo często z tych samych źródeł konstruują odmienne całości. Dwuznaczna pozycja samej historiografii wynika także z płynnej granicy między faktem, komentarzem, wnioskiem i konstrukcją. Pisarka ze sceptycyzmem podchodzi zatem do wielkich spekulacji historiozoficznych, domagając się od przedstawienia przeszłości „wszechstronnego opisu tego, co było" (Malewska 134).

Jeszcze radykalniejsze stanowisko wobec współczesnej historiografii zajmuje Parnicki. Autor Stowa i ciała zupełnie rezygnuje z pozycji powieściopisarza historycznego jako popularyzatora badań historycznych, nie chce powielać $\mathrm{w}$ fabularny i literacki sposób tego, co w badaniach historycznych zostało już ustalone. Przeciwnie, interesują go te miejsca wiedzy o przeszłości, które budzą wielkie wątpliwości. Powieściopisarz historyczny wkracza zatem tam, gdzie materiał historyczny pozostawia znaczące luki, gdzie należy wykorzystać wyobraźnię, by stworzyć różne hipotezy na temat możliwego przebiegu historii (Parnicki 1964; 1968), a w swoich powieściach próbuje zainscenizować sytuację niepewności poznania przeszłości na podstawie problematycznych źródeł, zmuszając czytelnika do ponownego rozważenia różnych hipotez i zmierzenia się z granicami poznania historycznego. Ten 
sposób wykorzystania wiedzy historycznej stawia przed czytelnikiem zupełnie nowe wymagania - nie jest on już biernym odbiorcą dokładnie przedstawionego świata historycznego, lecz staje się kimś, kto powinien samodzielnie rekonstruować wiedzę historyczną, korzystać z wielu - jak zaleca Parnicki krytykom (Parnicki 1965) - opracowań historycznych, a przede wszystkim dokładnie czytać, a właściwie badać, ukształtowany przez pisarza tekst powieści. Autora Srebrnych orłów irytują zarzuty niehistoryczności postaci z jego powieści. Krytycy, zanim napiszą coś o fikcyjnym charakterze postaci, powinni, według niego, zajrzeć do licznych słowników, encyklopedii, a także edycji źródeł historycznych. Model lektury, który projektuje Parnicki dla swoich czytelników, zakłada zatem specyficzną erudycję badawczą. Stwarza to świetną podstawę do zbudowania mitologii pisarza trudnego, niezrozumiałego i niedostępnego laikom, przeznaczonego wyłącznie dla wąskiego grona wtajemniczonych specjalistów (Parnicki 1971). Parnicki wzmacnia ten mit, porównując siebie do Eurypidesa, piszącego wyłącznie dla Sokratesa, a jednocześnie podkreśla duże nakłady swych wcześniejszych powieści, wyjawiając nadzieję, że kiedyś jego późniejsze powieści staną się czytelniejsze.

W ostatnich latach wielu pisarzy odchodzi od tej już obiegowej świadomości relatywizmu poznania historycznego i traktuje wiedzę historyków z dużo większą pokorą. Zapewne wynika to z przemian samej historiografii, która - w osobach takich teoretyków jak Hayden White - wykonała olbrzymią, choć nie zawsze powszechnie akceptowaną pracę nad własnymi ograniczeniami epistemologicznymi. Nie ma już zatem sensu kwestionować oczywistości faktu historycznego, gdyż dla niewielu poważnych badaczy fakt naukowy do dziś stanowi kluczowy fetysz ich dyscypliny. Przykładem takiego nowego stosunku pisarza historycznego do historiografii mogą być liczne wypowiedzi Elżbiety Cherezińskiej, w których autorka podkreśla współpracę z historykami, którzy dostarczają jej materiałów, sprawdzają faktografię, a czasem proponują rozwiązania powieściowych problemów, niekiedy współautorstwo $\mathrm{z}$ nimi. $\mathrm{W}$ posłowiach do powieści piastowskich autorka ujawnia, jak wielką inspirację stanowią dla niej prace współczesnych historyków takich jak Przemysław Urbańczyk (Urbańczyk 2010: 397), których prace w znaczący sposób odmieniły obraz początków państwa polskiego. Cherezińska ujawnia także, że jej powieści opierają się na konsultacjach z historykami, a czasem okazuje się, że historycy biorą udział w samym procesie twórczym. Nie ma tu zatem raczej mowy o specyficznej sytuacji trochę równości, a trochę konkurencji z zawodowymi historykami, jaką udało się stworzyć Parnickiemu. Być może wynika to z dużo większej specjalizacji współczesnych badań historycznych, które wymagają znacznie dłuższych studiów. Dla pisarza, nawet takiego jak Cherezińska, samodzielnie czytającego różne źródła (Cherezińska 2016: 568), oznacza to pewne ograniczenie własnej twórczości do prezentowania wyobrażonych, fikcyjnych scenariuszy, które mają udostępnić badania historyków w atrakcyjnej formie szerszej publiczności. 


\section{Przeszłość czy współczesność}

Drugi temat dotyczy relacji między przeszłością a teraźniejszością. Na ile powieść historyczna mówi o aktualnych problemach, a na ile ma nam dawać wiedzę o przeszłości, która nie potrzebuje żadnej aktualizacji? To pytanie trapiło wielu powieściopisarzy, a także historyków zmuszonych do odpowiedzi na wątpliwość, po co zajmować się odległą przeszłością, która zdaje się nie mieć nic wspólnego z teraźniejszością. Na te dyskusje nakładało się oczywiście zagadnienie politycznego, ideologicznego czy historiozoficznego uwikłania powieściopisarstwa historycznego. Szczególnie w czasach powojennych tworzenie literatury historycznej oznaczało przyjęcie jakiejś wyrazistej identyfikacji - katolickiej albo marksistowskiej (zob. Szymutko 33).

Dla wielu twórców ukazanie odległych czasów miało ułatwić rozpoznanie jakiegoś odwiecznego ładu albo reguł procesu historycznego. Współczesność przeszłości wynikała zatem z tego, że tak naprawdę nic się nie zmienia, a przeszłe wydarzenia dają łatwiejszy dostęp do tego, co w dziejach istotne, gdyż znika wielość nieznaczących faktów, które przeszkadzają w analizie dzisiejszej sytuacji. Z takiej perspektywy Malewska pisze, że w powieści historycznej historia powinna być "oświetlająca i sądząca współczesność. Nawet nie tyle może współczesność szeroko pojętą, co teraźniejszość, dziś, hic et nunc" (Malewska 137). Skrajnym przykładem takiego wykorzystania przeszłości będą historyczne alegorie czy moralitety (szerzej na temat tej konwencji w literaturze powojennej zob. Błażejewski) często służące do odniesienia do kontrowersyjnych aktualnych problemów, szczególnie społeczeństwa totalitarnego i jego moralnych oraz prawnych (takich jak cenzura, zob. Malewska 237) zagadnień.

Ciekawy sposób podważenia alternatywy między powieścią historyczną i współczesną wybiera Gołubiew:

W samym terminie „powieść historyczna” kryje się zasadnicze nieporozumienie; antycypując końcowe wnioski chciałbym od razu podważyć samo przeciwstawienie powieści „historycznej” $\mathrm{i}$ „współczesnej”. Moim bowiem zdaniem każda powieść jest mniej lub bardziej historyczna, ogromna zaś większość klasycznie historycznych powieści dotyczy problematyki współczesnej (Gołubiew 16).

Autor Bolesława Chrobrego uzasadnia swoją teze przykładem Lalki jako powieści zarazem współczesnej i historycznej, powieści, której zasięg czasowy rozciąga się na wiele dziesięcioleci przed latami pisania jej przez Bolesława Prusa. W drugą stronę - od historii do współczesności - prowadzi natomiast droga takich utworów jak Krystyna córka Lawransa Sygrydy Undset czy Faraon Bolesława Prusa. Pierwsza 
na materiale historycznym ma ukazywać antynomię świętości i grzechu, dialektykę dobra i zła, natomiast druga - charakteryzować współczesne refleksje o państwie.

Dzisiejszą wersję tych rozważań przestawia Cherezińska, gdy zauważa, że „Cesarstwo i zjazdy panów Rzeszy mogą przypominać spotkania przywódców Unii Europejskiej” (Cherezińska 2016a), a w tym samym wywiadzie dodaje, że "mechanizmy polityki zostały takie same. Możni przy wyborze władcy wspierają słabszych kandydatów, by później mogli nimi sterować. Wspieramy wrogów naszych wrogów, żeby toczyć wojny nie na własnym terenie" (Cherezińska 2016a). Narracje o przeszłości zawdzięczają swoją zrozumiałość podobieństwu przeszłych i współczesnych sytuacji, a także ponadhistorycznemu obowiązywaniu praw, którymi rządzą się stosunki międzyludzkie. Powieść historyczna ma zatem podkreślać szczególność czy wyjątkowość losów własnego narodu, na przykład jego martyrologii albo dawnych sukcesów. Nowa powieść historyczna ma zaś „zadbać o PR polskiej historii" (Cherezińska 2016a).

Alternatywą dla tej aktualizacji historii mogą być liczne wypowiedzi o jednokrotności, niepowtarzalności dziejów, których studiowanie może dać wiedzę o istocie człowieka historycznego, ale nie powinno redukować historycznego dystansu między różnymi epokami. Przykładem takiego podejścia są liczne wypowiedzi Parnickiego, przede wszystkim te, w których pisarz irytował się na odbieranie historyczności jego postaciom. Podkreślał poświadczenie w źródłach historycznych wielu bohaterów swoich powieści, ale przede wszystkim sprzeciwiał się doszukiwaniu się w Heliodorze, agencie z II wieku p.n.e. cech współczesnego mu prokuratora stalinowskiego, Andrieja Wyszynskiego. Autor Tylko Beatrycze nie ograniczał się jednak do negacji powierzchownych podobieństw. Zdecydowanie odcinał się także od narzucania mu jakiejś historiozofii, zawsze podkreślając, że interesują go bardzo konkretne zagadki historyczne. Pokusił się nawet o odwrócenie kierunku w maksymie o historii jako nauczycielce życia - twierdził bowiem, że to wiedza o współczesności, dzisiejsze doświadczenie ma nam dać szansę dotarcia do przeszłych zdarzeń (Parnicki 1964).

Wykorzystanie przeszłych zdarzeń jest ważnym elementem mitologii artysty historycznego. Dziejopisarstwo pozwala bowiem mówić o współczesności w sposób bardzo daleki od dosłowności i precyzji. Ta niedookreśloność historii stwarza szanse na rozwinięcie olbrzymiego pola treści sugerowanych - a jednocześnie pozwala czytelnikowi samodzielnie spostrzec zbieżność znanej mu współczesności z daleką przeszłością. To rozpoznanie stanowi ważny element przyjemności poznawczej i estetycznej związanej z poznawaniem przeszłości za pośrednictwem powieści historycznej, a jednocześnie tworzy mit powieściopisarza, który za pomocą przeszłych zdarzeń komentuje współczesność, mówiąc wszystkim, że to już było. 


\section{Między literaturą popularną a eksperymentalną}

Trzeci temat sytuuje literaturę historyczną w kluczowej dla literatury nowoczesnej opozycji między literaturą popularną a literaturą wysoką, artystyczną. Powieściopisarze historyczni często odżegnywali się od wielu modernistycznych mitologii artystycznych - podkreślali mniejszą rolę natchnienia, spontaniczności, indywidualnego spojrzenia, jednostkowości artysty, a znacznie większą - pracy, wręcz rzemiosła, jak Parnicki twierdzący, że nie jest stwórcą swoich postaci, ale raczej kimś, kto „przekuwa” wcześniej istniejący już materiał w literaturę (Parnicki rozwija tę metaforykę w wykładach, zob. Parnicki 1980). Swoją praktykę pisarską porównywał zaś $\mathrm{w}$ wielu alegorycznych obrazach do warsztatu rzemieślniczego, w którym sam byłby czeladnikiem, ocenianym przez własne postaci.

Pamiętać jednak należy, że często ci sami pisarze, którzy uwypuklali skrupulatność własnych badań, zmierzali w stronę eksperymentów formalnych, które miały pozwolić odnowić powieść historyczną, a czasem stanowiły oryginalny skutek refleksji nad ograniczeniami źródła historycznego. Opozycją dla tych eksperymentów będą różne przykłady kreowania historycznych literackich światów, zwykle rozpisanych na wiele tomów, w lekturę których wciągnąć ma się czytelnik zafascynowany stworzoną przez pisarza rzeczywistością. Bardziej niż o intelektualną pracę czytelnika chodzi wtedy o bycie w fikcyjnym świecie rozrywki, często wspartym okołoliterackimi praktykami (takimi jak gry fabularne, komputerowe itp.).

W ciekawy sposób można uchwycić tę opozycję, analizując wypowiedzi Parnickiego i Cherezińskiej. Parnicki sam był kinomanem, ale dość ostro przeciwstawiał twórczość literacką sztuce filmowej. Według niego film dużo lepiej przedstawia obrazowy element przeszłości, w związku z czym literatura powinna zrezygnować z fragmentów opisowych, a skupić się na płaszczyźnie intelektualnej (Parnicki 1968a). Zupełnie inną argumentację wybiera Cherezińska, podkreślająca znaczenie współczesnych seriali historycznych. Literatura historyczna ma znaleźć w polskiej przeszłości równie ciekawe zdarzenia, które zdolne będą do konkurencji z zachodnimi fabułami, zaś historia Polski (gdyż "nie mamy się czego wstydzić”) powinna stać się „naturalnym tworzywem popkultury” (Cherezińska 2012: 735; Cherezińska 2016a).

Powieść historyczna jest gatunkiem od zawsze nastawionym na popularny charakter. Mitologia artysty czytanego, niezbyt trudnego w odbiorze stanowi jedną z najważniejszych charakterystyk twórcy, który powinien poruszać ważne (na przykład dla tożsamości narodu) sprawy w sposób popularny, a na pewno znacznie łatwiejszy niż czynią to zawodowi historycy. Przełamania tej mitologii dokonuje Parnicki, gdy decyduje się pisać w sposób trudny, stawiając czytelnikowi równie wielkie wymagania (a czasem większe) niż stawia dyskurs zawodowej historiografii. 


\section{Wobec figury Sienkiewicza}

Ostatni, czwarty temat ma dość szczególną, konkretną postać. O ile poprzednie charakterystyki mitologii powieściopisarstwa historycznego odwoływały się do abstrakcyjnych cech, to tu chodzi o stosunek do konkretnego pisarza. Trylogia Sienkiewicza tak mocno wpłynęła na polskie powieściopisarstwo historyczne, że sposób podejścia do wielkiego patrona określa pozycję większości pisarzy tworzących w tym gatunku. W XX wieku bardzo wielu autorów przyjęło wyraźną postawę antysienkiewiczowską, sprzeciwiając się właśnie mitologizacji przeszłości w okresie powojennym swoiste powieściowe polemiki z Trylogią stworzyli między innymi Malewska i Parnicki, a marksistowską krytykę przedstawił Jan Ziółkowski w Homines novi. W ostatnich latach wielu twórców zdaje się jednak zbliżać do tej mitologii artystycznej, jak choćby Wolski, który podkreśla, że chodzi mu o historie, które kończą się dobrze, a czytelnik może identyfikować się z pozytywnym bohaterem (Wolski 2011: 15). U autora historii alternatywnych Sienkiewiczowski wzorzec zaowocuje licznymi pogodnymi fabułami, w których indywidualne ofiary na rzecz ojczyzny przekładają się na indywidualne, a jednocześnie zbiorowe sukcesy Polski, która staje się - w jednej z historycznych alternatyw - tytułowym Mocarstwem.

Ten mit narracyjnego pokrzepiania serc został poddany krytyce przez wielu pisarzy - najsilniej chyba przez Parnickiego, który zawsze podkreślał wielki wpływ pisarstwa Sienkiewicza na własną wyobraźnię, ale jednocześnie deklarował, że sam wolałby raczej pokrzepiać umysły czy mózgi niż serca (Parnicki 1988). Krytyka Sienkiewicza to próba myślenia o przeszłości zamiast jej przeżywania, to krytyka zamiast prostej dumy. Polski powieściopisarz historyczny musi zatem ustosunkować się do mitu Sienkiewicza. Mitologiczna genealogia oferuje mu miejsce córki (jak Zofia Kossak-Szczucka określana jako „córa Sienkiewicza”) czy kolejnych potomków noblisty. A negacja tej kłopotliwej czasami przynależności rodzinnej zmusza od razu do budowania jakiegoś antymitu.

Aktualność figury Sienkiewicza jako powieściopisarza historycznego potwierdza nie tylko ogromna literatura przedmiotowa, ale przede wszystkim literackie polemiki wokół estetycznych i ideologicznych aspektów Sienkiewiczowskiego modelu powieści historycznej. Przedstawiona w Trylogii wizja historii zdaje się zatem wciąż ważnym sposobem myślenia o polskiej przeszłości i tożsamości - to mit sarmacki, który ciągle podlega krytyce, przepracowaniu, a równocześnie jest podtrzymywany w licznych rytuałach. Sarmacki charakter polskiej przeszłości został, szczególnie w ostatnich latach, poddany wielostronnej, zarówno aprobatywnej, jak i krytycznej lekturze (zob. np. Czapliński). 


\section{Podsumowanie}

Badanie mitologii powojennego pisarstwa historycznego pozwala nakreślić współrzędne mapy pozycji, jakie zająć może pisarz historyczny. Próba pisania powieści historycznej zawsze oznacza konfrontację z artystycznymi mitologiami gatunku, który od razu proponuje różne gotowe wizerunki czy pozycje. Większość pisarzy w jakiś sposób akceptuje elementy tej konwencji - chce popularyzować historiografię bardziej niż poddawać ją krytyce, chce czynić mniej lub bardziej skomplikowane aluzje do współczesności, chce tworzyć utwory czytelne i popularne. Stanowisko antymitologiczne zajmuje w pełni Parnicki, wybierający zupełnie inną drogę - zakładającą napięcie między historią jako instytucją, czytelnikiem oraz ideologią.

Cztery tematy - płaszczyzny określania polskiego pisarstwa historycznego można byłoby pokazać na pewno w ujęciu bardziej historycznym. Wydaje się jednak, że w polu powieściopisarstwa historycznego znacznie istotniejsza jest trwałość pewnych pozycji niż ewolucja całego pola. Dlatego też ciekawsze niż opisywanie przemian powieści historycznych $\mathrm{w}$ kolejnych dziesięcioleciach jest uchwycenie pewnych stałych reguł owego dyskursu, które nie ulegają zmianie. Kolejne kryzysy i wzloty powieści historycznej zmuszają bowiem autorów do ustosunkowania się do podobnych problemów, choć wyrażonych czasem przez nowe teksty, zdarzenia czy sytuacje.

\section{BIBLIOGRAFIA}

Bartoszyński, Kazimierz. Powieść w świecie literackości. Warszawa: Instytut Badań Literackich PAN, 1991.

Błażejewski, Tadeusz. Historiozofia retoryczna. Formy paraboliczne i apokryficzne w polskiej prozie wspótczesnej. Łódź: Wydawnictwo Uniwersytetu Łódzkiego, 2002.

Burska, Lidia. Kłopotliwe dziedzictwo. Szkice o literaturze i historii. Warszawa: Wydawnictwo IBL, 1998.

Cherezińska, Elżbieta. Gra w kości. Poznań: Wydawnictwo Zysk i S-ka, 2010.

Cherezińska, Elżbieta. Korona śniegu i krwi. Poznań: Wydawnictwo Zysk i S-ka, 2012.

Cherezińska, Elżbieta. „Nie można opowiadać o swojej historii przeciwko innym. Między dumą, a pychą jest wielka przepaść". Rozmawiała Anna Sobańda. Dziennik 08.10.2016. Web 30.09.2018.

Cherezińska, Elżbieta. Królowa. Poznań: Wydawnictwo Zysk i S-ka, 2016a.

Chomiuk, Aleksandra. Między stowem a przeszłością. Strategie dokumentarne w polskiej powieści historycznej ostatniego pótwiecza. Lublin: Wydawnictwo Uniwersytetu Marii Curie-Skłodowskiej, 2009.

Czapliński, Przemysław. Resztki nowoczesności: dwa studia o literaturze i życiu. Kraków: Wydawnictwo Literackie, 2011.

Gołubiew, Antoni. Świadkowie przemian. Kraków: Znak, 1974.

Malewska, Hanna. O odpowiedzialności i inne szkice. Wybór publicystyki (1945-1976). Oprac. A. Sulikowski. Kraków: Znak, 1987. 
Nycz, Ryszard. Jezyk modernizmu. Prolegomena historycznoliterackie. Wrocław: Wydawnictwo Leopoldinum, 1997.

Parnicki, Teodor. „Zmyślenie a prawda historyczna”. Kierunki 8 (1964). S. 1-5.

Parnicki, Teodor. „Zwierzenia powieściopisarza historycznego czyli rozmowa z Teodorem Parnickim”. Rozmowę przeprowadził A. Piotrowski. Kierunki 39 (1965). S. 1-4.

Parnicki, Teodor. „Łamigłówki historii. Z Teodorem Parnickim rozmawia Krystyna Nastulanka”. Polityka 9 (1968). S. 1-7.

Parnicki, Teodor. „Powieść to jakby rozwiązywanie łamigłówki...”. Rozmowę przeprowadził K. Mętrak. Kultura 32 (1968a). S. 1-3.

Parnicki, Teodor. „Rozmowa z Teodorem Parnickim”. Rozmowę przeprowadził W. Jamroziak. Nurt 1 (1971). S. 5-8.

Parnicki, Teodor. Historia w literaturę przekuwana. Warszawa: Czytelnik, 1980.

Parnicki, Teodor. „Pokrzepić umysły. Rozmawiamy z Teodorem Parnickim, laureatem Nagrody Literackiej Przewodniczącego CK SD". Rozmowę przeprowadził A. Lenar. Kurier Polski 87 (1988). S. 1-2.

Szymutko, Stefan. Rzeczywistość jako zwattpienie w literaturze i literaturoznawstwie. Katowice: Wydawnictwo Uniwersytetu Śląskiego, 1998.

Urbańczyk, Przemysław. „Posłowie”. Cherezińska, Elżbieta. Gra w kości. Poznań: Wydawnictwo Zysk i S-ka, 2010. S. 397-398.

Wolski, Marcin. „O pożytku z historii alternatywnych”. Exploring the Benefits of the Alternate History Genre / W poszukiwaniu pożyteczności gatunku historii alternatywnych. Red. Z. Wąsik, M. Oziewicz, J. Deszcz-Tryhubczak. Wrocław: Wydawnictwo Wyższej Szkoły Filologicznej we Wrocławiu, 2011. S. 13-20.

Ziółkowski, Jan. Homines novi. Warszawa: Czytelnik, 1955. 
